\title{
About servants and flagellants: Seneca's Capitol description and the variety of 'ordinary' religious experience at Rome
}

\begin{abstract}
In introducing the idea of an "ordinary religious experience", the present paper makes a first attempt at providing a framework for understanding and explaining religious experiences that do not necessarily depend on ecstatic states of joy or exaltation. An approach to ordinary experience rather highlights an aspect of practice that involves the "modelling" of valued relationships for the sake of the experience of that particular relationship itself. As an analysis of three fragments of Seneca's treatise "on superstition" (Frg. 34-36) will demonstrate, Roman individuals sought to model and experience a personal closeness, a friendship even, with their addressed gods. To this end, these worshippers appropriated various practices from contexts of ritualized friendship for their ritualized practices with which they established and thereby experienced a mutual and benevolent bond with the addressed deity.
\end{abstract}

\section{Introductory remarks}

Depictions of the religious life at Rome during the Late Republican and Early Imperial periods reveal a variety of religious experiences. Whereas religious experiences come readily to the fore when investigating "ecstatic practices"1 such as the raising of arms, ${ }^{2}$ charismatic healing, ${ }^{3}$ frenetic dancing and wailing, ${ }^{4}$

1 "Ecstatic practices" refer to practices that one would intuitively understand as being in some sense "excessive" (Wulff 1991, 71-82).

2 According to comments made by Tertullian (Tert., Apol. 30.4) and Aristotle (Aristot., De mundo 400a16), raised hands were commonly regarded as a central element in prayer (Sittl 1890, 187-198; Ohm 1948, 14-60. 231-239; Hamman 1980, 1212-1219; Demisch 1984, 107-147; Guittard 1995, 81-110). The emotional impact of these gestures is stressed in Quint., Inst. 11.3.114-116. From a comparative perspective, the raising of the arms as illustrated by Quintilian might be thought to correspond with the so-called "jerking exercise" in Methodist churches (Wulff 1991, 76-77).

3 See Gordon 1995; Ov., Ars am. 315-336.

4 Women, for instance, toss their heads and wail in a certain manner (ululare). For examples, see Lucan. 5.152-157; Liv. 3.7.7. 26.9.6-8; Ov., Fast. 3.213-223. 4.313-320. 6.513-515; Ov., Met. 3.726-727. 7.180-191. 257-258. 9.770-773; Tac., Ann. 11.31.2; Juv. 3.212-215. See Šterbenc Erker 2011, 182-188. Modern approaches to religious experience highlight this ritual pattern as a strategy for religious experience (Rouget 1985, 12-14; Bourguignon 2004; Theodoridou 2009).

Ә Open Access. ( 2020 Maik Patzelt, published by De Gruyter. (c) BY-NC-ND This work is licensed under a Creative Commons Attribution-NonCommercial-NoDerivatives 4.0 International License.

https://doi.org/10.1515/9783110557596-007 
and self-mutilating, ${ }^{5}$ Seneca's fragments on superstition point towards religious experiences in the context of non-ecstatic practices, such as introducing guests, announcing the time to Jupiter, or going through the motions of doing Juno's hair. Seneca's writings thus make scholars of ancient religions aware of the fact that "religious experiences" or "emotions" may encompass much more than mere sensory stimulations. Some religious experiences may not even depend on these stimulations at all. As M. McGuire once argued in the case of Christian welfare workers, even the act of cooking a meal may already elicit fundamental religious experiences, even experiences of divine presence, without any manipulation of the senses. ${ }^{6}$ This observation leaves us with the question of how to detect these non-arousing experiences in our material and how we can apply such a theory to our ancient material.

In introducing the idea of an "ordinary religious experience", the present paper makes a first risky attempt at providing a framework for understanding and explaining religious experiences that do not necessarily depend on ecstatic states of joy or exaltation. Having introduced this concept, this contribution examines two essential fragments of Seneca's treatise “On Superstition”. After briefly examining the allegedly "superstitious" character of these practices, I turn to the role of individual agents who embed themselves into situations in which they gain experiences, and who ultimately ascribe a religious quality to these experiences.

\section{Religious experience, experience deemed religious, and ordinary experience}

\subsection{Framing religious experience: ecstatic practices and hysteric moments}

The primary question I will seek to answer is: what is a religious experience and how can we detect one in our (ancient) sources? This is a question that has

\footnotetext{
Likewise, male priests, such as the Salians, dance and sing in a similar way (Plut., Num. 13.4-5; Dion. Hal., Ant. Rom. 2.70.4-5).

5 This mostly refers to the priests of Cybele, who supposedly perform their rites in the same way as the frenetic women, but additionally cut their arms and castrate themselves (Ov., Fast. 4.221-246. 339-348; Sen., Vit. beat. 26.8; Sen. Frg. 34 = apud August., De civ. D. 6.10; Mart. 3.24. 3.81. 11.72. 81. 13.63; Juv. 6.513-516; Lucr. 2.614-623; Luk., Syr. Dea 50-51).

6 McGuire 2008, 104-112.
} 
attracted the interest of scholars for more than a hundred years already. Psychological, cognitive and anthropological approaches outline a variety of (cognitive) mechanisms that lead to an experience of divine or otherwise supernatural provenance. As already sketched in the introductory chapter of this book section, these mechanisms can broadly be clustered around two poles of argumentation. One pole argues that religious experience is triggered by certain brain activities in the amygdala and its surroundings. ${ }^{7}$ The other pole argues that embodiment plays a fundamental role. ${ }^{8}$ This is to say, they emphasize the importance of cultural learning and interactive meaning-making in the generation of religious experiences. Coming from this perspective, every experience, just as every feeling (cf. Goldie 2000, 28-37. 84-122; Damasio 2010, 108-129), is understood as a qualitative ascription that is fundamentally based on the socialization of the individual and their situation within a specific time and place, namely, the moment of practice. Strictly speaking, an experience is not inherently religious but can, rather, be "deemed religious" by the respective individual's perception of the moment (Taves 2009, 16-55).

Before we go any further, it will be useful to define what the term "religious" is supposed to mean in the context of experiences. Rather than trying to unpack the philosophical, sociological, or historical dimensions of the terms "religion", "religious", and "religiosity", ' I will restrict myself to defining "religious" from a basal cognitive perspective. Experiences and practices can count as religious as soon as - in Jörg Rüpke's words - the situational inclusion of "not unquestionably plausible actors" in communication is detected, ${ }^{10}$ which is to say, once a deity is expected to be involved.

When it comes to tracking down which experiences are deemed religious or divine and which not, an intriguing degree of attention has been paid to (the embodiment of) sensory manipulations of body and mind. ${ }^{11}$ Among many other

7 As most popularly expressed by D’Aquili and Newberg 1999. Criticism by Schjoedt 2009, 315-318; Jensen 2014, 117-118; Taves 2009, 17-22; Atran 2002, 181-186.

8 "Religious experience is an embodied, complex, essentially cognitive phenomenon, for which thoughts and beliefs are central" (Azari et al. 2005, 272). Cf. Barsalou et al. 2005; Schjoedt 2009, 322-325; Taves 2009, 56-87.

9 For an overview of "religion" through various disciplines, see Bergunder 2012; Taves 2011. "Religious" does not, however, mean the same thing as "religion". Whereas the one marks a complex belief system and its institutions, the other marks the quality of something (Taves 2009, 24).

10 Rüpke 2015. Cf. Rüpke 2016, 27-35; McCauley and Lawson 2002, 8-9. 23-37; McCauley and Lawson 1996, 110-121; Taves 2009, 39-46; Hick [2006] 2010, 27-29. Recently theorized as predictive coding in agency detection by Andersen 2019; Andersen and Schjoedt 2017. 11 Overview by Kundtová Klocová and Geertz 2019, 76-80; Geertz 2010, 306-308. 
modes of sensory manipulation, such as drug induction, two sensory modes enjoyed much attention in this field of study. ${ }^{12}$ One mode involves highly stimulating sensory practices, a sensory pageantry as it were, that cause something like an "overstimulation" of the brain, ${ }^{13}$ variously resulting in states of "dissociation" or "hypnotic induction" that may or may not be deemed "possession". ${ }^{14}$ The other mode involves various strategies of deprivation that may result in socalled states of "mindfulness" or "mystical experiences". ${ }^{15}$ These include the strategies involved in incubations at Asclepia or in the styles of prayer advocated by Seneca, Origen, or Evagrius. ${ }^{16}$ Non-arousing and non-manipulating practices, it seems, tend to lack attention as a basis for proper religious experiences, without saying that they are entirely ignored. ${ }^{17}$

\subsection{Ritualizing an "ordinary" religious experience}

This chapter, on the contrary, seeks to suggest that an approach based on embodiment also has the potential for investigating religious experiences that fall outside the stereotypical ritual schemata of trance, ecstasy, "collective effervescences” (Durkheim [1912] 1995, 217-231; cf. Turner 1974, 80-154) or, as recently conceptualized for students of classics, of "emotional communities" (Chaniotis 2013, Chaniotis 2016; cf. Belayche 2003). This sort of approach allows an investigation that goes beyond questions of sensory manipulation and dissociation, even if it does not require that we abandon these questions in their entirety.

12 Further types are out-of-body experiences or lucid dreams (Taves 2009, 11-12. 74-78; Oesterreich 1921, 25-37. 37-87).

13 Harvey Whitehouse 2004, 65-82 opposes the rather arousing "imagistic mode" to a "doctrinal mode". Cf. McCauley and Lawson 2002, 179-212. Approaches testing this model on ancient and medieval religions provided by Koskull 2011; Gragg 2004; Clark 2004.

14 Deeley et al. 2014; Jegindoe et al. 2013; McNamara 2009, 44-58; Taves 2009, 74-86; Atran 2002, 188-192. A small research history about the techniques for possession might be Girgensohn 1921; Oesterreich 1921, 16-24; Caillois 1964, 97-111; Rouget 1985, 11-39; Wulff 1991, 71-82.

15 Deprivation approached by calmness or, as McNamara suggests, as deep awareness (McNamara 2009, 55-58). Cf. Rouget 1985, 11-12. Defining an experience as "mystical" (Forman 1999; D’Aquili and Newberg 1999, 25-42) is, however, highly controversial.

16 For the incubation at the Asclepia, see Petsalis-Diomidis 2005, 198-217; Petridou 2016. For Origen, it is worth considering the monumental work of Perrone 2011. On Evagrius Ponticus and Isaac of Nineveh in relation to these concerns, see Bitton-Ashkelony 2011.

17 Tanya Luhrmann's model of cultivating the senses for divine presence does not necessarily need any arousing stimuli, even though the Evangelicals, which she is studying, do not spare dramatic ways to manipulate bodily and mental states (Luhrmann 2013; 2012). 
Matthias Jung's pragmatist considerations about “ordinary experiences” serves as perfect tool to that end.

As Jung correctly notes, most cognitive approaches to (non-)religious experience tend to ignore the agent's “positionality" (Positionalität, Jung 2014, 8588), ${ }^{18}$ which is the individual's capacity to perceive and therefore to experience a situation not just sensorially but also symbolically. Jung sets the aspect of a "symbolic consciousness" against the processual, and thus mono-dimensional, cognitive reference system of image-making that dominates within the cognitive studies (Jung 2014, 54-56. 85-88). In other words, the notion of ordinary experience prioritizes the experience of those qualities ascribed to symbols, signs, and their respective values, which are deeply rooted in everyday life. Amongst such qualities or "values", which cognitive studies would otherwise be barely able to grasp, are friendship and freedom.

Adapting Jung's concept of "ordinary experience" to the study of "religious experience" extends the analysis of experiences deemed religious in a profound way towards the experience of symbols and values that are - due to the holistic nature of an experience - immediately evoked by the execution of a practice. ${ }^{19}$ This sort of approach towards "ordinary religious experiences" does not, thus, attempt to investigate whether and how an experience of divine presence can be embodied in, and thus triggered by, particular practices that are acted out in their respective particular moments (e.g. public rituals). Directing a study towards "ordinary religious experiences" encourages the consideration of perceived qualities, such as valued relationships of friendship, as experiences deemed religious. Focusing on "ordinary religious experiences" also encourages the consideration of an ability of the individual to carry out various strategic maneuvers that establish and maintain these valued relationships with a deity.

This notion of ritual practice as a "strategic way of acting" corresponds with C. Bell's concept of ritualization. This is to say, Bell deploys a notion of embodiment that does not reduce ritual practice to a set of particular embodied

18 „Indem wir uns artikulieren, erzeugen wir höherstufige Bewertungen und ordnen unsere unmittelbare Erfahrung in ein holistisches, symbolisches Netzwerk der Wirklichkeitsdeutung ein“ (Jung 2014, 87). Cf. Jung 2016. Humphrey and Laidlaw make exactly the opposite point. Their understanding of ritualization contains a loss of a conscious being-in-the-world (Humphrey and Laidlaw 1994, 135-136).

19 As he indicates himself (Jung 2014, 10). Jung emphasizes that a particular experience does not necessarily have to indicate something special or ecstatic, although it can be referred to something special, such as a divine agent or agents. McNamara confirms this basic idea to some degree from a cognitive point of view, when he emphasizes that any religious practice evokes a religious experience (McNamara 2009, 148). 
body techniques that are acquired for particular ritual occasions. ${ }^{20}$ By transforming Pierre Bourdieu's notion of "practical mastery” (Bourdieu [1976] 2012, 139-202) into "ritual mastery", Bell (1992, 107-117) instead pinpoints the dialectic between the (ritual) body and its (ritual) environment, thus revealing the importance of the variety of embodied practices in religious contexts. According to Bell, "ritualization is the strategic manipulation of 'context' in the very act of reproducing it" (Bell 1992, 100). In pursuit of that aim, "ritualization could involve the exact repetition of a centuries-old tradition" but it can also involve a “deliberately radical innovation and improvisation" (Bell 1992, 91, emphasis mine). In this sense, the notion of ritual mastery pinpoints the integration - or in de Certeau's terms, the "appropriation" (1984, 29-42) - of all sorts of practices, whether already embodied or recently learned, into the concurrent moment of practice in order to "deal with some specific circumstances" of that particular moment (Bell 1992, 92). These circumstances might involve the need to experience certain values elicited by these ritualized practices.

What distinguishes practical mastery from ritual mastery are the intrinsic strategies of "differentiation", a "play of differences" as Bell calls them (Bell 1992, 105, cf. 90-93. 101-107). Bell reveals differentiation as the curtain behind which all practices appear as "special” or "extra-ordinary". ${ }^{21}$ In Bourdieu's terms, the play of differences supports the "distinction" of (religious) practice (Bell 1992, 90-93). Repetitions, reductions, changes of rhythms, changes of speed, and even a changed environment indicate the ritualized practice as both being and not being displaced at the very same time (Bell 1992, 88-93; Schieffelin 1996, 61). Ritual mastery does not, thus, merely include a creative sequencing of acts. Rather, it is also a creative way to develop and slightly alter them. Therefore, Bell's approach to ritualization also facilitates the identification of those techniques that are of the highest importance in cognitive studies and the psychology of religion. The crucial aspect of differentiation fits well with the basic scheme of ecstatic practices, as Stanley Tambiah, for instance, illustrates in respect to so-called "sacred language" (Tambiah 1968, 182-188; cf. Rouget 1985, 12-62; McNamara 2009, 173). The emergence of a frenetic and

20 In the words of Humphrey and Laidlaw (1994, 260-261), these embodied body techniques are "waiting for acting out". Ritual practices are therefore considered as "learned, transmitted, and shared by all those in a particular social and cultural milieu" (Humphrey and Laidlaw 1994, ch. 6, cit. 134). For this notion of embodiment in studies of prayer, see Norris 1999. In general Price et al. 2012.

21 "Specialness" (Taves 2009, 26-48); “Otherness” (Jensen 2014, 61-131; Humphrey and Laidlaw 1994, 101-103); “das Besondere” (Rüpke 2016, 24. 35-39). 
histrionic loss of self in practice does not, however, necessarily imply the individual's intention to lose his or her mind.

\section{Seneca's objection to idolatry or: unquestionably superhuman agents}

According to Seneca, the belief of the majority of Romans that statues are instantiations of divine presence, ${ }^{22}$ and not merely depictions or representations of deities, is a ridiculous superstition. Seneca enriches his complaints by drawing on popular views of the social lives and the emotions of the gods in order to ridicule the belief in corporally and emotionally present social beings that are able to communicate and even to marry (Sen. Frg. 31-33; 39). ${ }^{23}$ Since Seneca's criticism mainly derives from his philosophical rejection of idolatry (cf. Sen. Ep. 10.4-5; 41.1-2; 95.46-50), ${ }^{24}$ all the beliefs and practices which he considers "superstitious" may, rather, indicate a commonly shared cognition $^{25}$ according to which human worshippers find themselves interacting directly with a feeling (unquestionably superhuman) agent who is present with his or her body and mind.

22 Given the tremendous debate concerning this issue, see recently Eich 2011 and Weddle 2010.

23 "Sacros," inquit, "inmortales, inuiolabiles in materia uilissima atque inmobili dedicant, habitus illis hominum ferarumque et piscium, quidam uero mixto sexu, diuersis corporibus induunt; numina uocant, quae si spiritu accepto subito occurrerent, monstra haberentur." Deinde aliquanto post, cum theologian naturalem praedicans quorundam philosophorum sententias digessisset, obposuit sibi quaestionem et ait: "Hoc loco dicit aliquis: Credam ego caelum et terram deos esse et supra lunam alios, infra alios? Ego feram aut Platonem aut Peripateticum Stratonem, quorum alter fecit deum sine corpore, alter sine animo?" Et ad hoc respondens: "Quid ergo tandem, inquit, ueriora tibi uidentur Titi Tatii aut Romuli aut Tulli Hostilii somnia? Cloacinam Tatius dedicauit deam, Picum Tiberinumque Romulus, Hostilius Pauorem atque Pallorem taeterrimos omnium affectus, quorum alter mentis territae motus est, alter corporis ne morbus quidem, sed color. Haec numina potius credes et caelo recipies?" [. . . "Quid quod et matrimonia, inquit, deorum iungimus, et ne pie quidem, fratrum ac sororum! Bellonam Marti conlocamus, Vulcano Venerem, Neptuno Salaciam. Quosdam tamen caelibes relinquimus, quasi condicio defecerit, praesertim cum quaedam uiduae sint, ut Populonia uel Fulgora et diua Rumina."

24 Detailed discussion by Setaioli 2007; Merckel 2012, 82-89.

25 The notion of superstition in relation to these fragments has been challenged by Rüpke 2011, 51-54; Estienne 2001; Bendlin 2006, 310-311; Merckel 2012, 90-96. 


\section{The first scene: bloody frenzy and mass castrations at Rome?}

Seneca illustrates his argument against the alleged superstitious furor of idolatry with the following scene:

One castrates himself, another cuts his arms. Where will they find room for the fear of these gods when angry, who use such means of gaining their favor when propitious? But gods who wish to be worshipped in this fashion should be worshipped in none. So great is the frenzy of the mind when perturbed and driven from its seat, that the gods are propitiated by men in a manner in which not even men of the greatest ferocity and fable-renowned cruelty vent their rage. Tyrants have lacerated the limbs of some; they never ordered any one to lacerate his own. For the gratification of royal lust, some have been castrated; but no one ever, by the command of his lord, laid violent hands on himself to emasculate himself. They kill themselves in the temples. They supplicate with their wounds and with their blood. If anyone has time to see the things they do and the things they suffer, he will find so many things unseemly for men of respectability, so unworthy of freemen, so unlike the doings of sane men, that no one would doubt that they are mad, had they been mad with the minority; but now the multitude of the insane is the defense of their sanity.

(Transl. Philip Schaff) $^{26}$

The scene Seneca describes here is not truly representative, since we can be relatively certain that the majority of Roman citizens, the group Seneca addresses here, did not spend their lives as castrated persons. It seems clear to me that Seneca does not agitate against "Oriental cults" in general, or against the Galloi in particular, so as to favor Roman cults by contrast. ${ }^{27}$ Instead, the example of Phrygian self-mutilation serves as an overarching framework for the condemnation of every kind of (public) religious ritual undertaken by the majority of Romans. The point he wishes to make is that they are all as excessive as the Phrygian rituals. ${ }^{28}$

26 Sen., Frg. 34 = Sen. apud August., De civ. D. 6.10: Ille, inquit, uiriles sibi partes amputat, ille lacertos secat. Ubi iratos deos timent qui sic propitios merentur? Dii autem nullo debent coli genere, si hoc uolunt. Tantus est perturbatae mentis et sedibus suis pulsae furor ut sic dii placentur quem ad modum ne quidem homines saeuiunt taeterrimi et in fabulas traditae crudelitatis. Tyranni lacerauerunt aliquorum membra, neminem sua lacerare iusserunt. In regiae libidinis uoluptatem castrati sunt quidam; sed nemo sibi, ne uir esset, iubente domino manus tulit. Se ipsi in templis contrucidant, uulneribus suis ac sanguine supplicant. Si cui intueri uacet, quae faciunt quaeque patiuntur, inueniet tam indecora honestis, tam indigna liberis, tam dissimilia sanis, ut nemo fuerit dubitaturus furere eos, si cum paucioribus furerent; nunc sanitatis patrocinium est insanientium turba.

27 For such readings and for critical responses, see Turcan 1967, 30-37; Lausberg 1970, 211-225; Alvar 2008, 1-9; Merckel 2012, 67-96.

28 In his small treatise on the good life (de vita beata), Seneca uses a similar but more detailed strategy in order to oppose Stoic philosophy with the ecstatic behavior that takes place in front of the temples, to which Seneca also refers pontifical practices (Sen., Vit. beat. 26.7-8). 
The explicit plurality of the respective temples (in templis) makes this point very clear, as does the closing statement: "the multitude of the insane is the defense of their sanity." Later on, these excesses are even declared to be "commanded by the laws" (Sen. Frg. 39), ${ }^{29}$ i.e. by Roman tradition. Seneca attacks these strategies for sensory (over)stimulation as being too deeply rooted in the religious arrangements of Rome, just as Polybius (6.56.9-11) had implied some 200 years earlier.

While many other sources reflect similar concerns about charismatic, hysteric, and even self-mutilating rituals, and Seneca even goes so far as to include the public prayers of magistrates and their prompting pontiffs in this category, this scene also fulfills an important narratological function. After repeatedly mentioning the clichéd act of self-castration several times in a short space, Seneca then compares the self-mutilating and self-castrating masses with those who carry out non-ecstatic personal services for the gods. Seneca uses this explicit and intuitive narrative of self-mutilation to introduce the intense emotional impact of carrying out the non-mutilating services described below.

\title{
5 The bloodless frenzy: experiencing the relationship with a deity
}

\subsection{Establishing a valued relationship strategically}

\begin{abstract}
Still there is a fixed time for this frenzy. It is tolerable to go mad once in the year. But go to the Capitol, and you will be ashamed of the folly there disclosed, and of the duties (officia) which a deluded madness has assigned itself. One servant informs Jupiter of the names of his worshippers, another announces the hours; one is his bather, another his anointer, that is, he gestures with empty hands to imitate the act of anointing. There are women who are hairdressers for Juno and Minerva: while standing far away from the temple as well as from the image they move the fingers as if they were dressing the hair, and there are others who hold a mirror. There are men who summon the gods to give bond for them, and some who offer them lawyers' briefs and explain their case [...].
\end{abstract}

(Transl. Philip Schaff) ${ }^{30}$

29 Omnem istam ignobilem deorum turbam, quam longo aeuo longa superstitio congessit, sic, inquit, adorabimus, ut meminerimus cultum eius magis ad morem quam ad rem pertinere.

30 Sen., Frg. 35-36 = apud August., De civ. D. 6.10: Huic tamen, inquit, furori certum tempus est. Tolerabile est semel anno insanire. In Capitolium perueni, pudebit publicatae dementiae, quod sibi uanus furor adtribuit officii. Alius nomina deo subicit, alius horas Ioui nuntiat, alius lutor est, alius unctor, qui uano motu bracchiorum imitatur unguentem. Sunt quae Iunoni ac Mineruae capillos disponant (longe a templo, non tantum a simulacro stantes digitos mouent 
The persons described here do not appear as priests performing formalized ritual practices of oriental provenance. They do not even appear as devoted servants carrying out specific ritual services that are connected to some particular temple, as the temporal distinction from annual festivities emphasizes. They behave, rather, as household personnel, houseguests, clients, and flatterers, who seek to establish a personal bond with the deity. ${ }^{31}$ They enact a morning salutation, in which the three gods, but particularly Jupiter Optimus Maximus, are considered the hosts. The most obvious salutation agent is the servant who informs Jupiter about the names of his other guests. He appears as a nomenclator. ${ }^{32}$ The second person similarly appears as a house servant who is in charge of organizing time, a human cuckoo-clock so to speak, who likewise asserts control over the salutation and banqueting procedures. ${ }^{33}$ The other persons fit perfectly into this scheme as well, notwithstanding that one or the other function - the anointment for instance - may also appear in particular cult contexts. The following scene from Seneca's 95th letter to Lucilius underlines my point:

Let us forbid lamps to be lighted on the Sabbath, since the gods do not need light, neither do men take pleasure in soot. Let us forbid men to offer morning salutation (salutatio) and to throng the doors of temples; mortal ambitions (ambitio) are attracted by such services (officia), but God is worshipped by those who truly know Him. Let us forbid bringing towels and flesh-scrapers to Jupiter, and proffering mirrors to Juno; for God seeks no servants. $^{34}$

(Transl. E. Phillips Barker)

Seneca illustrates the services performed here amidst the morning salutation much more explicitly as "strategic ways of action." By referring the advantage of this salutation to an ambitio, Seneca flags up the reciprocity for which the agents are obviously striving: these agents are only interested in performing officia because they expect a favor in return (Saller 2002, 15). Seneca accuses them of instantiating or maintaining a selfish, reciprocal relationship to the gods. However, Seneca does not stigmatize these attempts as a sort of bribery,

ornantium modo), sunt quae speculum teneant; sunt qui ad uadimonia sua deos aduocent, sunt qui libellos offerant et illos causam suam doceant [...].

31 Whereas Estienne differentiates between common ritual practices and "pratiques sociales humaines" in this scene (Estienne 2001, 199-201), Bendlin seems to regard all these practices as "social rituals" (Bendlin 2006, 310-311). MacMullen (1981, 43-46) refers to so-called "folk religion".

32 On nomenclatores, see Mommsen [1887] 1952, 356-359.

33 Mart. 8.67; Petron. 26.9; Juv. 10.216.

34 Sen., Ep. 95.47. This salutation scene is also framed by an attack against idolatry in favor of Seneca's Stoic conceptions of God, which are mentioned in the quoted text (Sen., Ep. 95.46. 50). 
as do a number of other authors (e.g. Pers. 2). Neither does a simple reciprocal schema involving a generalized or balanced exchange of favors explain the heightened emotionality about which Seneca openly complains (cf. Rüpke 2011, 53; Rüpke 2013). It is only by comparing the behavior of these individuals to the ritualized practices of the morning salutation in aristocratic households that we can really discover what sort of "return" was expected.

A brief survey of morning salutations at Rome suffices to show that the most valuable return for various officia is found in the apodictic certainty of a personal closeness to the addressee (Goldbeck 2010, 235-246. 264-277). Right from the start of the salutation, a complex system of exclusion and inclusion in time and space establishes and stages this certainty. As soon as the clients and friends arrive at the house of a (usually aristocratic) host, they are divided and thereby graduated into several groups, with the most important meeting with the host soonest and in the smallest numbers, whereas the least important persons join a large group at the end of the morning (Sen., Ben. 6.33.4-34.3). ${ }^{35}$ The practical mastery manifests itself in various services which the guests provide to the host in these contexts. From offering exotic food to washing feet, everything is possible that complements, substantiates, and specifies a reciprocal relationship and, thereby asserts the personal closeness for which these agents are striving. ${ }^{36}$ In short, morning salutations at Rome involved a variety of ritualizations of ordinary practices that establish a close relationship - indeed a friendship - for the duration of the practice.

The (religious) ritual mastery in the presence of the statues follows the same reciprocal logic as the (social) ritual mastery performed at the houses of aristocrats, as Seneca displays perfectly when he disparages the respective function of each "idolatrous” practice. By holding lamps, telling names, or anointing, the human agents integrate the deity into a reciprocal relationship for the sake of this relationship itself. The salutations in the temples do not, thus, display strict formalized performances. Rather, they provide examples of a "practically mastered idolatry" that is carried out by each individual. While the anointers and hairdressers may have been inspired by the more or less formalized rituals of Isis, Cybele, or Dea Dia (cf. Apul., Met. 11.9; Ov., Fast. 4.133-348), none of these goddesses appears in the scenes described. The agents seek to dominate or "master" the current circumstances by taking communicative practices from a range of contexts and appropriating them,

35 Pro honore dare, ut ostio suo propius adsideas, ut gradum prior intra domum ponas, in qua deinceps multa sunt ostia, quae receptos quoque excludant.

36 A long list of services is provided by Friedländer [1922] 1979, 248-253. 
reshaping them, and even innovating in order to achieve the goal of an apodictic certainty of personal closeness to a deity. ${ }^{37}$

Against this background, Seneca's attack on Jewish practices such as the lighting of a lamp makes much more sense. On first impression, one might wonder why Jews should consider the Sabbath observance as a daily service that enables an unspecified plurality of gods to see in the dark. There are further good grounds for rejecting the common interpretation that Seneca is here agitating against the Jews of Rome: the weekly Sabbath observance was already an essential Jewish practice and, more importantly, an identity marker for Jewish groups in Seneca's times (Barclay 1996, 440-442). Moreover, Jewish specialists were not unknown in the public sphere of Rome (Juv. 6.520-564; Hor., Sat. 1.9.67-72). A daily performance of Sabbatical rites by Jews is, thus, as unlikely as a misreading of their practices by Seneca. Since Roman authors such as Ovid advertise the Sabbath for its erotic charm (Ov., Ars am. 1.75), Seneca may rather agitate against those who appropriated the service of holding a lamp, because they recognized in it a personal service that could be offered to any god. ${ }^{38}$

A closer look at the distance of practitioners from the statues offers an insight into the purest sense of Bell's concept of ritualization, namely that people attempt to dominate, shift, or nuance a competitive situation towards their own advantage (Bell 1992, 106-108). At least to my eyes, it is striking that the farther away the agents are from the statues, the closer they should theoretically be in order to perform their services properly. The anointer and hairdressers, for instance, should have the deity right at hand and not far away. Acting at a distance may imply a competitive situation that requires a certain degree of creativity to navigate, that is to say a practical mastery that differentiates the agents' own practices from those of the other agents around. On the other hand, they could also merely be attempting to cope with the fact that these particular statues were enormous and that it was impractical given the difference in size between human and god to carry out the services in a straightforward manner. In any case, these practices indicate an attempt to establish a close personal relationship with the deities.

37 The same can be detected in banqueting scenes (Scheid 2005; Veyne 2000) and even in public lectisternia (Habinek 2005, 36-44).

38 As mentioned for the rites of the Arval Brethren (Scheid 1990, 627-628). For non-Jews appropriating Jewish practices, see Katell Berthelot in this volume. 


\subsection{The furor of an "ordinary religious experience"}

Since Seneca starts his polemical documentation with the most excessive ritual available to him at Rome, it is clear that his primary goal is to pinpoint the emotional impacts in the subsequent Capitoline scene. Whereas the Capitol description clearly confirms the aroused minds of the "servants" by ascribing states of furor or dementia to them, the passage in the letters clearly indicates their individual attempts to establish a reciprocal relationship with the gods. In the words of Matthias Jung, the "servants" experience the symbolic value or "quality" of their personal interactions, which is immediately evoked by the execution of practice and which they strategically nuance in pursuit of their end. Certain women, who Seneca describes in a subsequent fragment as appearing in Jupiter's temple and believing they are beloved by the deity, definitely made the best attempt in this respect. As he explicitly states, these women intensively experience the value of the relationship that they impose on their interaction with Jupiter, namely love and intimacy (Sen., Frg. 37).

The calendric reference confirms the suspicion that these intense experiences derive from the experience of strategically established valued relationships. These people neither prefer nor depend on collective effervescences or emotional communities for their religious experience. Similarly, no leading ritual agent, such as a magistrate or a priest, controls either the practices in pursuit of an experience or the articulations of these experiences. In consequence, the divine essence is not experienced through the projection of conscious, subconscious, or sensory stimulations onto the deity, who functions as a direct reference. The experience is, rather, of an indirect and holistic sort. By this I mean that the interaction automatically instantiates a symbolic level of a relationship that is experienced at the very moment in which the interaction is executed. The "plausible agents" are participants in an interaction and this interaction, in turn, acquires a symbolic quality, such as friendship, because of their participation. This situation perfectly expresses the notion of an ordinary religious experience: a religious experience does not need any inherently religious practices. ${ }^{39}$ These people evidently "appropriated" various practices from a wide range of occasions and circumstances in order to master, or even dominate, the current situation in front of the temples.

39 „Selbst höchste außeralltägliche Erfahrungsmodi, etwa religiöse, ästhetische oder moralische Grenzerfahrungen, können dann in diesem, strukturellen Sinn gewöhnlich sein, auch wenn es ihre Inhalte offensichtlich nicht sind“ (Jung 2014, 10). 
By ritualizing and appropriating various communication practices in accordance with the reciprocal logic applied in friendship, the agents appear to have nuanced the meaning of these practices to bring them into line with their personal goals, to wit, certain degrees of personal closeness to the deity. Otherwise, Seneca would not lay so great an emphasis on the "ordinary" meaning of these practices, namely slave-services. He tries to adjust the "original" connotations of these practices to the current situation, whereas, in fact, these practices had already lost the "original" significance due to their "manipulation" towards a "valued relationship”, as Bell would put it.

\subsection{Concessions: ecstatic states}

Despite the fact that close personal relationships are necessarily accompanied by the respective qualitative experiences, Seneca's description also indicates the presence of those particular modes of religious experiences that are debated by scholars who approach these actions from a (neuro-)psychological perspective. This especially concerns the aspect of differentiation discussed above. This differentiation is best expressed by the fact that people sit in front of the closed temple doors, well-equipped and willing to fulfil their particular tasks. Whereas bathing or anointing is just one element among others during processions, the agents at the Capitol and at more distant temples seem to repeat the same practice throughout their service. They conform to the differentiation strategies of reduction and repetition. According to scholars of cognition, the repetition of particular ritualized patterns, and/or the exaggerated performance of such patterns, often tends to lead to histrionic takeovers. The agents lose intentionality and thereby fall into ecstatic, indeed dissociative states that may or may not lead to the experience of an "internal personal alien control" or, to put it more simply, "possession". 40

The famous morning visits with which Scipio Africanus honored the Capitoline Jupiter confirm this view (Liv. 26.19.4-9; Gell. 6.1.6.; Val. Max. 1.2.2). As Livy points out, Scipio's mind was possessed by somewhat superstitious thoughts or practices (capti quadam superstitione animi), by which he means that Scipio was practicing highly arousing "superstitious" rituals of the sort that John Scheid and Paul Veyne have identified with ecstatic prophetic practices (Scheid 1998, 176-180; Veyne 1989, 184-185). In this regard, Scipio spent

40 Deeley et al. 2014; McNamara 2009, 167-192; Atran 2002, 165-169. From an anthropological point of view, see Rouget 1985, 17-46. 
his morning visits, which Livy connects to the daily cycle of salutations, ${ }^{41}$ engaged in a frenetic and arousing ritualization. In this way, his behavior corresponds with that of the prophetic Sybil or, indeed, with Appian's depictions of Scipio's own religious frenzy before a battle. ${ }^{42}$

Similarly, the Sabbath, which Seneca aligns with all the other services, is connected to ecstatic practices by some Roman and Greek authors. Juvenal and Plutarch, for instance, align Sabbath observances with other superstitious practices that are deemed extreme and ecstatic. For these writers, keeping the Sabbath is similar to supplicating in barbarian words (i.e. speaking in tongues), writhing in mud, or self-mutilation in the Phrygian style (Plut., De superst. $3 \mathrm{~d}$. 7d; Juv. 6.535-564). If we treat the Capitoline scene and the letter's scene as emerging from a single shared context, Seneca's notion of furor seems to confirm these notions of ecstatic experiences in Jewish practices.

This brief comparative survey will, I hope, suffice to show that, although ecstatic practices and experiences are not necessary, such experiences are nevertheless possible. The servants could lose themselves in their respective practice. These transitions into an altered level of conscious experience, however, are not to be confused with the primary intention of ritualizing services. They merely intensify or complement the ordinary religious experiences of divine closeness.

\section{Conclusion}

In my introduction, I asked: (a) how can we detect religious experience in our sources, and (b) how does this affect our overall view of religiosity, religious belief, and religious practice in antiquity?

With regard to the first question, my results will be rather unsatisfying for those who wish to extract a generalized framework that elucidates religious experiences in all contexts and on all occasions. Whereas the commonly applied models for ecstatic and dissociative experiences might be ideal for such a task, my considerations rather provide tentative access to something I referred to as “ordinary religious experience”. Seneca's polemic against individual religious

41 The formulation nullo die prius ullam publicam priuatamque rem egit, quam in Capitolium iret is to be understood this way (Liv. 26.19.5).

42 "He followed their movement, gazing at them and crying out like one possessed. The whole army, as it saw him turning hither and thither, imitated his actions, and all were fired with the idea of certain victory" (App., Hisp. 26). 
practices exemplifies the variety of experiences deemed religious that go beyond altered states of consciousness. His account illuminates the fact that religious experiences do not necessarily depend on ecstatic or dissociative states. Likewise, the concepts of ritual mastery and ordinary experience clearly shift the idea of ritual embodiment, in the sense of an individual's rehearsed performance, to the notion of an individual's unique, situational, and therefore ephemeral practice. Ritualized practices can also be structured by a rather mundane strategic logic that aims at "modelling" valued relationships for the sake of the experience of that particular relationship itself.

Given this background, it is worth considering a pragmatist reading of belief. Coming from this point of view, knowledge and cognition are not simply pre-reflexive but, rather, self-reflexive. That is to say, cognition results from action. Acting at a certain moment shapes the individual's cognitive map and therefore evokes new expectations for prospective actions (Jung 2014, 37-74; Joas 1996, 232-237). ${ }^{43}$ From this perspective, it is exactly those experiences that are deemed religious or divine that support the belief in a divine presence - $a$ belief about which Seneca complains. As long as no skepticism arises about the nature of the statue or the success of the communication, there is no need to doubt the divine presence. That process can tentatively be recognized in the salutation scenes. People act out a personal relationship that they emotionalize. In experiencing this relationship, the presence of the deity becomes perceptually real. Once performatively established, there is an ongoing expectation that such a warm relationship with the deity can be re-established. Religious experience is, thus, a driving force for the making of belief. ${ }^{44}$

\section{Bibliography}

Alvar, Jaime 2008. Romanising Oriental Gods: Myth, Salvation, and Ethics in the Cults of Cybele, Isis, and Mithras, transl. and ed. Richard Gordon. Leiden.

Andersen, Marc 2019. “Predictive Coding in Agency Detection”, Religion, Brain \& Behavior 9. 65-84.

Andersen, Marc; Schjoedt, Uffe 2017. "How does Religious Experience Work in Predictive Minds?”, Religion, Brain, and Behavior 7. 320-323.

Atran, Scott 2002. In Gods We Trust: The Evolutionary Landscape of Religion. Oxford.

43 For cognitive approaches on this notion of personal belief and its relation to culture and belief systems, see Leeuwen and van Elk 2018; Barret and Lanman 2008.

44 If this is accepted, then John Scheid's $(2015,113)$ assumption that "emotion did not form the basis or origin of belief and practice" would be falsified. 
Azari, Nina P. et al. 2005. "Religious Experience and Emotion: Evidence for Distinctive Cognitive Neural Patterns", The International Journal for the Psychology of Religion 75. 263-281.

Barclay, John M.G. 1996. Jews in the Mediterranean Diaspora: From Alexander to Trajan (323 $B C E-117(E)$. Edinburgh.

Barrett, Justin L.; Lanman, Jonathan A. 2008. “The Science of Religious Beliefs”, Religion 38. 109-124.

Barsalou, Lawrence W. et al. 2005. “Embodiment in Religious Knowledge”, Journal of Cognition and Culture 5. 14-57.

Belayche, Nicole 2003. «En quête de marqueurs des communautés 'religieuses' grécoromaines. » In Les communautés religieuses dans le monde gréco-romain: Essais de definition, ed. Nicole Belayche, Simon C. Mimouni. Turnhout. 9-20.

Bell, Catherine 1992. Ritual Theory: Ritual Practice. Oxford.

Bendlin, Andreas 2006. „Nicht der Eine, nicht die Vielen: Zur Pragmatik religiösen Verhaltens in einer polytheistischen Gesellschaft am Bespiel Roms." In Götterbilder, Gottesbilder, Weltbilder: Polytheismus in der Welt der Antike, vol. 2, ed. Reinhard G. Kratz, Hermann Spieckermann. Tübingen. 279-312.

Bergunder, Michael 2012. „Was ist Religion? Kulturwissenschaftliche Überlegungen zum Gegenstand der Religionswissenschaft“, Zeitschrift für Religionswissenschaft 19. 3-55.

Bitton-Ashkelony, Brouria 2011. "The Limit of the Mind (NOUS): Pure Prayer according to Evagrius Ponticus and Isaac of Nineveh”, Zeitschrift für antikes Christentum 15. 291-321.

Bourdieu, Pierre [1976] 2012. Entwurf einer Theorie der Praxis. Frankfurt/M.

Bourguignon, Erika 2004. „Suffering and Healing, Subordination and Power: Women and Possession Trance", Ethos 32. 557-574.

Caillois, Roger 1964. Die Spiele und die Menschen: Maske und Rausch. München.

Chaniotis, Angelos 2013. "Staging and Feeling the Presence of God: Emotion and Theatricality in Religious Celebrations in the Roman East." In Panthée: Religious Transformations in the Graeco-Roman Empire, ed. Laurent Bricault, Corinne Bonnet. Leiden. 169-189.

Chaniotis, Angelos 2016. "Displaying the Emotional Community: The Epigraphic Evidence." In Emotion and Persuasion in Classical Antiquity, ed. Ed Sanders, Matthew Johncock. Stuttgart. 93-111.

Clark, Anne L. 2004. "Testing the Two Modes Theory: Christian Practice in the Later Middle Ages.” In Theorizing Religions Past, Archaeology: History, and Cognition, ed. Harvey Whitehouse, Luther H. Martin. Walnut Creek. 125-142.

Csordas, Thomas J. 1997. The Sacred Self: A Cultural Phenomenology of Charismatic Healing. Berkeley.

D'Aquili, Eugene; Newberg, Andrew B. 1999. The Mystical Mind: Probing the Biology of Religious Experience. Minneapolis.

Damasio, Antonio 2010. The Self Comes to Mind: Constructing the Conscious Brain. New York. de Certeau, Michel 1984. The Practice of Everyday Life. Berkeley.

Deeley, Quinton et al. 2014. "Modelling Psychiatric and Cultural Possession Phenomena with Suggestion and fMRI”, Cortex 53.107-119.

Demisch, Heinz 1984. Erhobene Hände: Geschichte einer Gebärde in der bildenden Kunst. Stuttgart.

Durkheim, Émile [1912] 1995. The Elementary Forms of Religious Life. New York.

Eich, Peter 2011. Gottesbild und Wahrnehmung: Studien zu Ambivalenzen früher griechischer Götterdarstellungen (ca. 800 v. Chr. - ca. 400 v. Chr.). Stuttgart. 
Estienne, Sylvia 2001. "Le 'dévots' du Capitole: Le 'culte des images' dans la Rome impériale », MEFRA 113. 189-210.

Forman, Robert K.C. 1999. Mysticism, Mind, Consciousness. Albany.

Friedländer, Ludwig 1979 [1922]. Darstellungen aus der Sittengeschichte Roms: In der Zeit von Augustus bis zum Ausgang der Antonine, vol. 1. Aalen.

Geertz, Armin W. 2010. "Brain, Body and Culture: A Biocultural Theory of Religion”, Method and Theory in the Study of Religion 22. 304-321.

Girgensohn, Karl 1921. Der seelische Aufbau des religiösen Erlebens: Eine religionspsychologische Untersuchung auf experimenteller Grundlage. Leipzig.

Goldbeck, Fabian 2010. Salutationes: Die Morgenbegrüßungen in Rom in der Republik und der frühen Kaiserzeit. Berlin.

Goldie, Peter 2000. The Emotions: A Philosophical Exploration. Oxford.

Gordon, Richard 1995. "The Healing Event in Graeco-Roman Folk-Medicine.” In Ancient Medicine in its Sociocultural Context, ed. Herman F.J. Horstmanshoff et al. Leiden. 363-376.

Gragg, Douglas L. 2004. “Old and New in Roman Religion: A Cognitive Account.” In Theorizing Religions Past, Archaeology: History, and Cognition, ed. Harvey Whitehouse, Luther H. Martin. Walnut Creek. 69-86.

Guittard, Charles 1995. Recherches sur le Carmen et la prière dans la littérature latine et la religion romaine. Paris.

Habinek, Thomas 2005. The World of Roman Song: From Ritualized Speech to Social Order. Baltimore.

Hamman, Adalbert 1980. "La prière chrétienne et la prière paienne: Formes et différences ", ANRW II 23.2. 1190-1247.

Hick, John [2006] 2010. The New Frontier of Religion and Science: Religious Experience, Neuroscience and the Transcendent. Basingstoke.

Humphrey, Caroline; Laidlaw, James 1994. The Archetypal Actions of Ritual: A Theory of Ritual Illustrated by the Jain Rite of Worship. Oxford.

Jegindoe, Else-Marie E.; Vase, Lene; Jegindoe, Jens; Geertz, Armin W. 2013. "Pain and Sacrifice: Experience and Modulation of Pain in a Religious Piercing Ritual”, International Journal for the Psychology of Religion 23. 171-187.

Jensen, Jeppe S. 2014. What is Religion? Durham.

Joas, Hans 1996. Die Kreativität des Handelns. Frankfurt/M.

Jung, Matthias 2014. Gewöhnliche Erfahrung. Tübingen.

Jung, Matthias 2016. "Qualitative Experience and Naturalized Religion: An Inner Tension in Dewey's Thought?" In The Varieties of Transcendence: Pragmatism and the Theory of Religion, ed. Hermann Deuser et al. Fordham. 91-104.

Koskull, Maximilian 2011. Radikale und gemäßigte Geißler: "modes of religiosity” im Spätmittelalter. Marburg.

Kundtová Klocová, Eva; Geertz, Armin W. 2019. “Ritual and Embodied Cognition.” In The Oxford Handbook of Early Christian Ritual, ed. Risto Uro et al. Oxford. 74-94.

Laderman, Carol 1991. Taming the Winds of Desire: Psychology, Medicine, and Aesthetics in Malay Chamanistic Performances. Berkeley.

Lausberg, Marion 1970. Untersuchungen zu Senecas Fragmenten. Berlin.

Luhrmann, Tanya 2012. When God Talks Back: Understanding the American Evangelical Relationship with God. New York. 
Luhrmann, Tanya 2013. “'Lord, Teach Us to Pray’: Prayer Practice Affects Cognitive Processing”, Journal of Cognition and Culture 13. 159-177.

Leeuwena, Neil van; Elk, Michiel van 2018. "Seeking the Supernatural: The Interactive Religious Experience Model”, Religion, Brain and Behavior 8. 1-31.

Lewis, Ioan M. [1971] 2003. Ecstatic Religion: A Study of Shamanism and Spirit Possession. London.

MacMullen, Ramsay 1981. Paganism in the Roman Empire. New Haven.

McCauley, Robert N.; Lawson, E. Thomas 1996. Rethinking Religion: Connecting Cognition and Culture. Cambridge.

McCauley, Robert N.; Lawson, E. Thomas 2002. Bringing Ritual to Mind: Psychological Foundations of Cultural Forms. Cambridge.

McGuire, Meredith B. 2008. Lived Religion: Faith and Practice in Everyday Life. Oxford. McNamara, Patrick 2009. The Neuroscience of Religious Experience. Cambridge.

Merckel, Cécile 2012. Seneca theologus: La religion d'un philosophe romain. Strasbourg. Merleau-Ponty, Maurice 1945. La phénoménologie de la perception. Paris.

Mommsen, Theodor [1887] 1952. Römisches Staatsrecht, vol. 1. Basel.

Norris, Rebecca S. 1999. The Body in Prayer: A Comparative Study. Boston.

Oesterreich, Traugott K. 1921. Die Besessenheit. Langensalza.

Ohm, Thomas 1948. Die Gebetsgebärden der Völker und das Christentum. Leiden.

Perrone, Lorenzo 2011. La preghiera secondo Origene: L'impossibilità donata. Brescia.

Petridou, Georgia 2016. "Speaking Louder with the Eyes: Eye-shaped Ex-Votos in Context”, Religion in the Roman Empire 2. 372-390.

Petsalis-Diomidis, Alexia 2005. "The Body in Space: Visual Dynamics in Graeco-Roman Healing Pilgrimage." In Seeing the Gods: Patterns of Pilgrimage in Antiquity, ed. Ian Rutherford, Jas Elsner. Oxford. 183-218.

Price, Tom F. et al. 2012. "The Emotive Neuroscience of Embodiment", Motivation and Emotion 36. 27-37.

Rouget, Gilbert 1985. Music and Trance: A Theory of the Relations Between Music and Possession. Chicago.

Rüpke, Jörg 2011. Aberglauben oder Individualität: Religiöse Normabweichung im römischen Reich. Tübingen.

Rüpke, Jörg 2013. “On Religious Experiences That Should Not Happen in Sanctuaries.” In Memory and Religious Experience in the Greco-Roman World, ed. Nicola Cusumano et al. Stuttgart. 137-143.

Rüpke, Jörg 2015. "Religious Agency, Identity, and Communication: Reflecting on History and Theory of Religion", Religion 45. 344-366.

Rüpke, Jörg 2016. Pantheon: Geschichte der antiken Religionen. München.

Saller, Richard [1982] 2002. Personal Patronage under the Early Empire. Cambridge.

Scheid, John 1990. Romulus et ses frères: Le collège des frères Arvales, modèle du culte public dans la Rome des empereurs. Rom.

Scheid, John 1998. « Nouveau rite et nouvelle piété: Réflexions sur le ritus Graecus. » In Ansichten griechischer Rituale: Geburtstags-Symposium für W. Burkert, ed. Fritz Graf. Stuttgart. 168-182.

Scheid, John 2005. "Manger avec les dieux: Partager sacrificiel et commensalité dans la Rome antique. » In La cuisine et l'autel: Les sacrifices en questions dans les sociétés de la méditerranée ancienne, ed. Stella Georgoudi. Turnhout. 273-288. 
Scheid, John 2015. The Gods, the State, and the Individual: Reflections on Civic Religion in Rome. Philadelphia.

Schieffelin, Edward L. 1996. "On Failure and Performance: Throwing the Medium Out of the Séance.” In The Performance of Healing, ed. Carol Laderman, Marina Roseman. London. 59-90.

Schjoedt, Uffe 2009. "The Religious Brain: A General Introduction to the Experimental Neuroscience of Religion", Method and Theory in the Study of Religion 21. 310-339.

Setaioli, Aldo 2007. "Seneca and the Divine: Stoic Tradition and Personal Developments", International Journal of the Classical Tradition 13. 333-368.

Sittl, Carl 1890. Die Gebärden der Griechen und Römer. Leipzig.

Šterbenc Erker, Darja 2011. „Stimme und Klang im Bacchuskult: Die ululatio.“ In Laut und Leise: Der Gebrauch von Stimme und Klang in historischen Kulturen, ed. Erika MeyerDietrich. Bielefeld. 173-194.

Šterbenc Erker, Darja 2013. Religiöse Rollen römischer Frauen in „griechischen“ Ritualen. Stuttgart.

Tambiah, Stanley S. 1968. "The Magical Power of Words”, Man 3. 175-208.

Taves, Ann 2009. Religious Experience Reconsidered: A Building Block Approach to the Study of Religion and other Special Things. Princeton.

Taves, Ann 2011. "2010 Presidential Address: 'Religion' in the Humanities and the Humanities in the University”, Journal of the American Academy of Religion 79. 287-314.

Theodoridou, Natalia 2009. "Hysteria and Trance: Performative Synergies”, Contemporary Theatre Review 19. 195-203.

Turcan, Robert 1967. Sénèque et les religions orientales. Brüssel.

Turner, Victor 1974. The Ritual Process. Harmondsworth.

Veyne, Paul 1989. "La nouvelle piété sous l'empire: S’asseoir auprés des dieux, fréquenter les temples ", Revue de philologie, de littérature et d'histoire anciennes 63. 175-194.

Veyne, Paul 2000. «Inviter les dieux, sacrifier, banqueter: Quelques nuances de la religiosité gréco-romaine ", Annales. Histoire, Sciences Sociales 55. 3-42.

Weddle, Polly G. 2010. Touching the Gods: Physical Interaction with Cult Statues in the Roman World. Durham.

Whitehouse, Harvey 2004. Modes of Religiosity: A Cognitive Theory of Religious Transmission. Oxford.

Wulff, David M. 1991. Psychology of Religion: Classic and Contemporary Views. New York.

Xygalatas, Dimitris et al. 2013. "Extreme Rituals Promote Prosociality", Psychological Science 24. 1602-1605. 